\title{
Assessment of cyanobacteria biomass recourse potential in Ukrainian internal waters for environmentally friendly target production
}

\author{
Christina Soloviy, Myroslav Malovanyy \\ Department of Ecology and Sustainable Environmental Management Lviv Polytechnic National University, \\ UKRAINE, Lviv, Stepan Bandera street, 12, E-mail: mmal@lp,edu.ua
}

\section{Abstract - Assessment of perspective in using Ukrainian internal waters cyanobacteria biomass for multi-target production was conducted.}

Keywords - biomass, cyanobacteria, environmental threat, biotechnology, resource potential.

Searching for alternative energy sources under conditions of Ukrainian energy market alteration is specifically relevant. Among renewable energy sources that are used in world practice, prominent place takes biomass - wastes from wood processing, agricultural products, special forestry and agricultural energy plantings. In some regions cultivating and using plants as a source for energy carriers production has taken to such extent, that it led to reduction to agricultural production critical level and caused civil protests in some countries (Mexico, Latin America). This is why scientific efforts have been recently directed to searches for cultivating technologies and applying for energy producing biomass types, using of which wouldn't affect reduction of agricultural production potential opportunities and environmentally hazardous impact. Set of studies (Israel - Seambiotic company, Japan - Gas and NEDO companies, USA GreenFuel Technologies) have shown that algae can be the reguired biomass - both cultivated on special farms and harvested from hydrosphere surface objects. Such perspective for Ukraine is cyanobacteria (blue-green algea) that have been recently causing environmental threats due to progressive water blooming. Water «blooming», dominant agents of which for Dnieper reservoirs are representatives of Microcystis, Phormidium, Aphanizomenon, Anabeana and Oscillatoria genera is a biological signal of troubles in hydro-ecosystems. Among numerous mechanical, physical - chemical, biological and environmental methods for massive cyanobacteria development warning, the most effective are the last two, since they enable to avoid the cause, but not the consequences of water «blooming» [1]. Concerning perspectives for using them to obtain energy, then the most perspective solar energy utilizers appeared to be microalgae: maximum photosynthesis Energy conversion efficiency ratio gains $20 \%$. Energy that is contained in $1 \mathrm{~m}^{3}$ of biogass is equivalent to $0,6 \mathrm{~m}^{3}$ of natural gas or $0,7 \mathrm{dm}^{3}$ of crude oil or $0,6 \mathrm{dm}^{3}$ of diesel fuel. That is why using cyanobacteria during their massive development (so called «blooming») in Dnieper reservoirs water area to obtain biogas will enable to receive not only additional energy source but will lead to improvement of sanitary-hygienic water level and coastal areas. Problem for such biogas production technology is cyanobacteria harvest, that can be carried out with the help of special barge-harvesters [2].

Additionally cyanobacteria biomass processing aiming to obtain products of different purpose can be relevant for such industry fields as medicine, pharmacology, cosmetology and parfume industry, as well as for agriculture (obtaining of organic-mineral fertilizers and organic pesticides) [3, 4].

\section{Main part}

In our opinion in order to assess perspective biotechnologies of target products from Ukrainian internal water cyanobacteria biomass production it is necessary to conduct range of complex studies. First of all it is important to evaluate perspective of using cyanobacteria 
biomass resource potential for production of certain types of products: energy carriers, range of products from agricultural, medical, pharmacological, cosmetological and parfume industry. It is necessary to identify the most perspective types of cyanobacteria for application in each of these technologies and shape optimal application principles for these innovative technologies. It is worth to mention that for some products essentially important are toxicological facilities of cyanobacteria. These facilities are also vital for minimization of environmental threats from uncontrolled development of cyanobacteria in Ukrainian internal water. And last but not least it is important to study optimization and intensification of harvest processes, concentration and preliminary processing cyanobacteria in Ukrainian internal waters gaining its most effective application as resource potential in determined technologies that have been formerly studied.

As for perspectives from using resource potential of cyanobacteria to produce wide range of healthy products, then previously we suggested [3] scheme of biotechnological ways for complex processing of blue-green algae and fields for their application (Fig.1.)

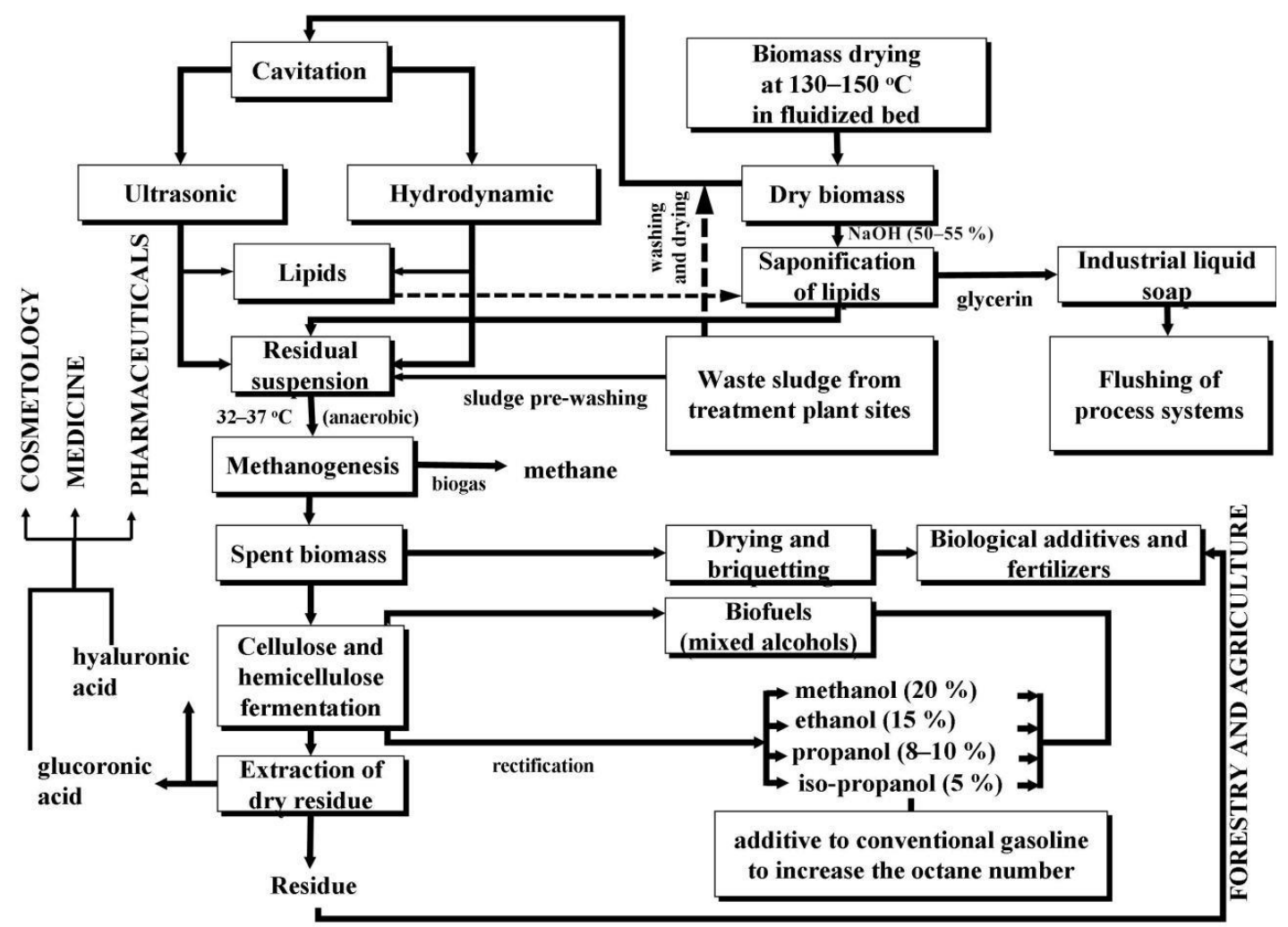

Fig.1. Biotechnological ways of blue-green algae complex processing and the industries of application of its products.

It has been fully studied on using cyanobacteria biomass resource potential of Ukrainian internal waters in energy carriers production technologies - implementation of methanogenesis technology with obtaining of condensed biogas $[1,2,4]$ and lipid extraction with obtaining of raw material for biodiesel production [4]. It has been proved possibility of receiving condensed organic fertilizers from residual biomass after obtaining of biogas [4], previously conducted studies require generalization and concretization, necessary development of studies for establishing perspective in using cyanobacteria as organic pesticides.

Aspects in using cyanobacteria biomass as resource material in medicine, pharmacology, cosmetology and parfume industry require detailed studies. This is because this biomass is potential source of chromoproteids (comples of coloured proteins that change their colour 
depending on uptake), including phycobiliproteins (red and blue pigments). Hemeproteins, flavoproteins and phycobilins are also present in this biomass. Pigments that are added to cosmetic mixtures improve skin tissue breathing hence facilitate rejuvenation.

Hyaluronic and glucuronic acids are of special interest. Their synthesis under production conditions is very complicated, that's why cyanobacteria biomass is valuable resource material for receiving these compounds. They are easily extracted from residual dry biomass via hydroalcohol extraction with further recrystallization under temperature above $(40-50)^{\circ} \mathrm{C}$. Under higher temperatures molecules of these multibasis organic acids lose biological activity since they become racemates or dycarboxylate.

\section{Conclusion}

Conducted analysis claims about perspective from using cyanobacteria biomass of resource material for production of variety products that are valuable in many industry fields and both agriculture. Important is that using this biomass as raw material it is possible simultaneously to reduce environmental threat from uncontrolled development of cyanobacteria in water areas of Ukrainian internal waters. Suggested algorithm of studies concerning identification of the most perspective types of cyanobacteria to concrete innovative technologies for target production.

\section{References}

[1] V.V.Nykyforov, S.V.Dehtiar and O.V.Shmandii Obespechenije ekolohycheskoi bezopasnosti Dneprovskoho baseina putjem ispolzovanyia hydrobyontov dlia polucheniya biohaza. Mashynostrojenije i bezopasnost zhyznedeiatelnosti, Vyp.5, pp. 51 - 56, 2008.

[2] V.V.Nykyforov, V.P.Alfjerov and V.M. Shmandii Yspolzovanye syne-zeljenyh vodoroslei dlia poluchenyia byohaza. Hyhyena y sanytaryia, №6.pp.33-37, 2010.

[3] V.Nykyforov, M.Malovanyy, T.Kozlovska, O.Novokhatko and S.Digtiar The biotechnological ways of blue-green algae complex processing. Eastern-European Journal of Enterprise Technologies, № 5(10), pp. 11-18, 2016.

[4] M.Malovanyy, V.Nikiforov, O.Kharlamova and O.Synelnikov Production of renewable energy resources via complex treatment of cyanobacteria biomass. Chemistry \& Chemical Technology, Vol.10, №2, - pp.251-254, 2016. 